\title{
Effect of salbutamol in infants with wheezy bronchitis
}

\author{
M. RADFORD \\ From the Department of Paediatrics, Cardiothoracic Institute and Brompton Hospital, and Department of \\ Child Health, Hammersmith Hospital, London
}

\begin{abstract}
Radford, M. (1975). Archives of Disease in Childhood, 50, 535 . Effect of salbutamol in infants with wheezy bronchitis. Using the technique of whole body plethysmography, lung mechanics were measured in a group of infants with wheezy bronchitis. Compared with a group of normal infants previously studied, airway resistance and thoracic gas volume were found to be raised. Nebulized salbutamol was then administered and measurements were repeated when it was found that there was no objective improvement. It is concluded that salbutamol may not be an effective form of treatment of wheezy bronchitis in young infants and the reasons for this are discussed.
\end{abstract}

Wheezy bronchitis in infancy, defined as respiratory distress with generalized expiratory rhonchi, is common in general paediatric practice, but the treatment of this condition varies widely from one centre to another (Elderkin et al., 1965; Wright and Beem, 1965). In particular, bronchodilator therapy is commonly given, but there is no good evidence that it is effective. In a previous communication (Radford, 1974) it was shown that airway resistance and lung volume can be reliably measured in infancy, and this makes it possible to assess the effect of various forms of treatment in an objective manner. The purpose of the present study was to test the effect of a commonly used bronchodilator, salbutamol, in infants with wheezy bronchitis.

\section{Subjects and methods}

Airway resistance and thoracic gas volume were measured in 10 infants with wheezy bronchitis. This was purely a clinical diagnosis based on a combination of tachypnoea, respiratory distress, and generalized expiratory rhonchi in infants weighing less than $10 \mathrm{~kg}$, and no attempt was made to subdivide the subjects on an aetiological basis. Most of them were only moderately sick and were studied at any convenient time during their illness. Others were more severely ill, requiring oxygen and intravenous fluids at the height of their illness, and were studied as soon as they were well enough to be nursed out of oxygen. Several had been treated with antibiotics, and some had received oral bronchodilator therapy, but not within the 6 hours preceding the study. Clinical and radiological features of the 10 infants are given in Table I.

Received 11 December 1974.
The infants were sedated with chloral hydrate, $60 \mathrm{mg} / \mathrm{kg}$, and airway resistance and thoracic gas volume were measured in a whole body plethysmograph as previously described (Radford, 1974). Salbutamol was then administered by blowing oxygen at $7 \mathrm{l} / \mathrm{min}$ through a Wright's nebulizer containing $10 \mathrm{ml} 0.5 \%$ salbutamol solution. The outlet of the nebulizer was connected to an open-ended nasal adaptor which was fitted into the infant's nose using silicone putty to make an airtight seal. The tubing from the nebulizer was of thick-walled rubber and kept as short as possible to minimize droplet deposition on its walls. The nebulization was continued for two minutes, and the radial pulse counted before and after. With practice it was found that this procedure could be carried out without waking the infant, and the measurements of airway resistance and lung volume were repeated about 20 min later. Mean values were calculated from three separate measurements before and after nebulization.

\section{Results}

Table II shows the results of airway resistance and thoracic gas volume in the 10 infants studied before giving salbutamol and compared with a group of 16 normal infants previously studied who fell into the same age range of 8-43 weeks. There was no significant difference between the mean age or weight of these two groups. Thoracic gas volume is expressed in relation to body weight, since it has been shown that there is a constant relation between these two parameters in normal infants (Howlett, 1972). Both airway resistance and thoracic gas volume were significantly higher in the group with wheezy bronchitis.

The effect of nebulization with salbutamol is 
TABLE I

Clinical details of infants with wheezy bronchitis

\begin{tabular}{|c|c|c|c|c|c|c|c|}
\hline Case no. & Sex & Age (w) & Weight (kg) & $\begin{array}{l}\text { Family history } \\
\text { of asthma }\end{array}$ & $\begin{array}{l}\text { Past history } \\
\text { of eczema }\end{array}$ & $\begin{array}{c}\text { Previous wheezing } \\
\text { attacks }\end{array}$ & Chest $x$-ray \\
\hline $\begin{array}{l}1 \\
2\end{array}$ & $\begin{array}{l}\mathbf{F} \\
\mathbf{F}\end{array}$ & $\begin{array}{l}14 \\
12\end{array}$ & $\begin{array}{l}6 \cdot 15 \\
5 \cdot 03\end{array}$ & $\stackrel{+}{-}$ & + & - & $\begin{array}{l}\text { Patchy opacities } \\
\text { both lower lobes } \\
\text { Patchy opacities } \\
\text { both lower lobes }\end{array}$ \\
\hline 3 & $M$ & 20 & $7 \cdot 95$ & - & - & - & Normal \\
\hline 4 & $\mathbf{M}$ & 13 & $5 \cdot 82$ & - & - & - & $\begin{array}{l}\text { Patchy opacity } \\
\text { R upper lobe }\end{array}$ \\
\hline 5 & $\mathbf{F}$ & 43 & $8 \cdot 52$ & - & + & + & Normal \\
\hline 6 & $\mathbf{M}$ & 26 & $7 \cdot 78$ & - & - & - & $\begin{array}{l}\text { Patchy opacity } \\
\text { L lower lobe }\end{array}$ \\
\hline 7 & $\mathbf{M}$ & 33 & $8 \cdot 20$ & - & - & - & $\begin{array}{l}\text { Patchy opacity } \\
\text { L lower lobe }\end{array}$ \\
\hline 8 & $\mathbf{F}$ & 13 & $6 \cdot 00$ & - & - & - & Normal \\
\hline 9 & $\mathbf{F}$ & 8 & $4 \cdot 87$ & - & - & + & Normal \\
\hline 10 & $\mathrm{~F}$ & 12 & $5 \cdot 49$ & - & - & + & Normal \\
\hline
\end{tabular}

TABLE II

Lung mechanics in normal infants and infants with wheezy bronchitis

\begin{tabular}{|c|c|c|c|c|c|}
\hline & \multicolumn{2}{|c|}{ Normal (no. $=16$ ) } & \multicolumn{3}{|c|}{ Wheezy bronchitis (no. $=10$ ) } \\
\hline & Mean & SD & Mean & SD & Difference \\
\hline $\begin{array}{l}\text { Age (wk) } \\
\text { Weight (kg) } \\
\text { Thoracic gas volume }(\mathrm{ml}) \\
\text { Thoracic gas volume } / \mathrm{kg} \text { body weight }(\mathrm{ml}) \\
\text { Airway resistance }\left(\mathrm{cm} \mathrm{H}_{2} \mathrm{O} / 1 \text { per } \mathrm{s}\right)\end{array}$ & $\begin{array}{l}16 \cdot 6 \\
5 \cdot 924 \\
210 \cdot 4 \\
35 \cdot 2 \\
20 \cdot 9\end{array}$ & $\begin{array}{l}8 \cdot 9 \\
1 \cdot 674 \\
73 \cdot 8 \\
6 \cdot 3 \\
8 \cdot 7\end{array}$ & $\begin{array}{l}19 \cdot 4 \\
6 \cdot 581 \\
306 \cdot 4 \\
47 \cdot 1 \\
33 \cdot 2\end{array}$ & $\begin{array}{l}11 \cdot 2 \\
1 \cdot 387 \\
77 \cdot 3 \\
10 \cdot 3 \\
10 \cdot 0\end{array}$ & $\begin{array}{l}\text { NS P } 0.503 \\
\text { NS P } 0.310 \\
\text { HS P } 0.004 \\
\text { HS P } 0.001 \\
\text { HS P } 0.003\end{array}$ \\
\hline
\end{tabular}

NS, not significant; HS, highly significant.

TABLE III

Effect of nebulized salbutamol in 10 infants with wheezy bronchitis

\begin{tabular}{|c|c|c|c|c|c|}
\hline & \multicolumn{2}{|c|}{ Before treatment } & \multicolumn{3}{|c|}{ After treatment } \\
\hline & Mean & SD & Mean & SD & Difference \\
\hline $\begin{array}{l}\text { Pulse/min } \\
\text { Thoracic gas volume }(\mathrm{ml}) \\
\text { Thoracic gas volume } / \mathrm{kg} \text { body weight }(\mathrm{ml}) \\
\text { Airway resistance }\left(\mathrm{cm} \mathrm{H}_{2} \mathrm{O} / 1 \text { per } \mathrm{s}\right)\end{array}$ & $\begin{array}{r}149 \\
306 \cdot 4 \\
47 \cdot 1 \\
33 \cdot 2\end{array}$ & $\begin{array}{l}13 \\
77 \cdot 3 \\
10 \cdot 3 \\
10 \cdot 1\end{array}$ & $\begin{array}{r}148 \\
309 \cdot 0 \\
47 \cdot 7 \\
35 \cdot 2\end{array}$ & $\begin{array}{r}12 \\
84 \cdot 3 \\
13 \cdot 3 \\
7 \cdot 6\end{array}$ & 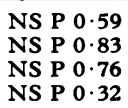 \\
\hline
\end{tabular}

shown in Table III. There was no significant change in thoracic gas volume, airway resistance, of pulse rate after this treatment.

\section{Discussion}

The clinical condition of wheezy bronchitis described here is one which is familiar to all paediatricians, and frequently divided into viral bronchiolitis and asthmatic bronchitis. In viral bronchiolitis this clinical picture follows a short period of fever and coryza, and is usually caused by the respiratory syncytial virus. In asthmatic bronchitis the condition is recurrent, often with no preceding symptoms or systemic upset, and frequently develops into childhood asthma. However, clinically it is often difficult to place an infant into one or other of these categories, and there is increasing evidence that these two conditions form part of a continuous spectrum of disease. Rooney and Williams (1971) followed up a series of infants with 
viral bronchiolitis, in whom respiratory syncytial virus had been isolated, and showed a high incidence of recurrent wheezing, which is known to be associated with a high incidence of asthma in later childhood (Williams and McNicol, 1969). Similar results were obtained by Eisen and Bacall (1963) and König, Godfrey, and Abrahamov (1972), though these authors did not perform viral studies. It seemed reasonable, therefore, to treat the clinical syndrome of wheezy bronchitis as a single entity for the purposes of this study.

The observed increase in airway resistance and thoracic gas volume in these infants is consistent with lower airways obstruction. Hyperinflation probably results from early closure of airways whose internal diameter is compromised by oedema or bronchospasm. Similar results are found in other forms of lower obstructive airways disease studied by plethysmography, such as asthma or fibrocystic disease (Dubois, Botelho, and Comroe, 1956; Cook et al., 1959; Meisner and Hugh-Jones, 1968). However, these are all studies on adults or older children. Comparable information on lung mechanics in infancy is very scanty and variable.

Phelan, Williams, and Freeman (1967) measured total pulmonary resistance and thoracic gas volume in infants with viral bronchiolitis, and found them both to be raised. They used an oesophageal balloon to measure intrapleural pressure and a pneumotachygraph to measure air flow at the nose and mouth, and measured thoracic gas volume in a plethysmograph. Wohl, Stigol, and Mead (1969) measured inspiratory and expiratory resistance in infants with bronchiolitis using the forced oscillatory technique of Dubois et al. (1955). They found a marked rise of expiratory resistance, but only a slight increase in inspiratory resistance, and did not measure lung volume.

The results of the present study clearly show that salbutamol, given in the manner described, has no beneficial effect on airways obstruction in wheezy bronchitis in infancy. The possible interpretations of this are that either it is genuinely ineffective, or it was not given in an effective manner. There has been a great deal of debate concerning the efficacy of aerosol administration of drugs. Bau et al. (1971) administered radioactively labelled nebulized water to subjects in a mist tent and scanned them immediately after. They found that though some radioactive water was deposited in the lungs, $90 \%$ of the radioactivity was localized in the stomach, presumably due to swallowing of droplets deposited in the posterior pharynx.

Nevertheless, bronchodilators given by aerosol are undoubtedly effective in asthma (Choo-Kang,
Parker, and Grant, 1970; Riding, Chatterjee, and Dinda, 1969). In the paediatric department of the Brompton Hospital, nebulized salbutamol is given to children aged 4 and over in an almost identical manner to that described here, and it is rapidly effective as judged by clinical improvement and increased peak flow (personal observation). Moreover, it has been shown that nebulized isoprenaline, when given to infants via a face mask, causes a brisk increase in heart rate, showing at least that it enters the systemic circulation (Phelan and Williams, 1969). For these reasons, it was concluded that salbutamol was given in an effective manner in this study, and therefore that it has no beneficial effect on airway obstruction in infancy.

These results tend to confirm a clinical impression, but there is very little published information on the effect of bronchodilators in wheezing conditions in infancy. Holland, Colley, and Barraclough (1960) found respiratory effort, as measured by intraoesophageal pressure swings, to be decreased in some cases of bronchiolitis and bronchopneumonia after injection of adrenaline. However, the number of subjects was small, the distinction between bronchiolitis and bronchopneumonia was not clear, and they made no attempt to measure airflow in and out of the lungs. Reynolds and Cook (1963) state that 'an occasional infant may improve with the administration of bronchodilator drugs', but publish no data to support this opinion. Phelan and Williams (1969) approached the problem more objectively; they studied 10 infants with viral bronchiolitis and measured total pulmonary resistance using an oesophageal balloon and a pneumotachygraph. They found no decrease of resistance after administration of nebulized isoprenaline or orciprenaline, and concluded that these drugs were ineffective in this condition. They were, however, unable to measure thoracic gas volume in these infants, which is an important index of the severity of obstructive airways disease.

Thus, it appears that there is some fundamental difference between the airways obstruction in this group of infants and in older children or adults with asthma. The pathology of lower airway obstruction in wheezy bronchitis is not clear. Studies in infants dying of viral broncholitis show the most severe lesions in bronchioles of calibre 75-300 $\mu \mathrm{m}$, with oedema of the bronchiolar wall, epithelial necrosis, and excess secretion of mucous associated with plugs of debris obstructing the lumen (Aherne et al., 1970). However, these represent the severe cases and pathological studies in mild cases are of course not available. It is 
therefore difficult to assess the relative importance of oedema of the bronchiolar wall and true bronchospasm, if such an entity exists.

Phelan and Williams (1969) state that in infants under the age of 12 months bronchial and bronchiolar muscle is thin and poorly developed and probably could not significantly narrow the lumen of the airway by contraction. It is true that bronchiolar muscle is less predominant in small airways and infants, but it does exist. Matsuba and Thurlbeck (1972) measured this and found that $6.5 \%$ of the bronchiolar wall of small infants in infancy was composed of smooth muscle compared with $14 \cdot 2 \%$ in adults. It does not necessarily follow, however, that this decreased amount of muscle is not capable of effective contraction.

In conclusion, it seems very likely that the structural basis of obstructive airways disease in infancy differs from that in older children with asthma, but the nature of the obstruction is poorly defined. Further study is required to assess the effect of bronchodilator and other forms of therapy so that rational treatment may be given in this very common condition.

I am grateful to Dr. H. V. Finlay and Dr. S. M. Tucker for allowing study of patients under their care, to the nursing staff of Hillingdon Hospital for help and assistance, to Dr. S. Godfrey for advice, and to Miss G. Earle for technical assistance. This work was supported by a grant from the Medical Research Council.

\section{REFERENCES}

Aherne, W., Bird, T., Court, S. D. M., Gardner, P. S., and McQuillin, J. (1970). Pathological changes in virus infections of the lower respiratory tract in children. Fournal of Clinical Pathology, 23, 7.

Bau, S. K., Aspin, N., Wood, D. E., and Levison, H. (1971). The measurement of fluid deposition in humans following mist tent therapy. Pediatrics, 48, 605 .

Choo-Kang, Y. F. G., Parker, S. S., and Grant, I. W. B. (1970). Response of asthmatics to isoprenaline and salbutamol aerosols administered by intermittent positive-pressure ventilation. British Medical fournal, 4, 465.

Cook, C. D., Helliesen, P. J., Kulczycki, L., Barrie, H., Friedlander, L., Agathon, S., Harris, G. B. G., and Shwachman, H. (1959). Studies of respiratory physiology in children II. Lung volumes and mechanics of respiration in 64 patients with cystic fibrosis of the pancreas. Pediatrics, 24, 181.
DuBois, A. B., Botelho, S. Y., and Comroe, J. H. (1956). A new method for measuring airway resistance in man using a body plethysmograph. Values in normal subjects and in patients with respiratory disease. Fournal of Clinical Investigation, 35, 327.

DuBois, A. B., Brody, A. W., Lewis, D. H., and Burgess, B. F. (1955). Oscillation mechanics of lungs and chest in man. Fournal of Applied Physiology, 8, 587.

Eisen, A. H., and Bacall, H. L. (1963). The relationship of acute bronchiolitis to bronchial asthma. A 4-to-14-year follow-up. Pediatrics, 31, 859.

Elderkin, F. M., Gardner, P. S., Turk, D. C., and White, A. C. (1965). Aetiology and management of bronchiolitis and bronchopneumonia in childhood. British Medical fournal, 2, 722.

Holland, W. W., Colley, J. R. T., and Barraclough, M. A. (1960). Measurement of respiratory effort and assessment of a method of treating lower-respiratory-tract infections in small children. Lancet, 2, 1166.

Howlett, G. (1972). Lung mechanics in normal infants and infants with congenital heart disease. Archives of Disease in Childhood, 47, 707.

König, P., Godfrey, S., and Abrahamov, A. (1972). Exerciseinduced bronchial lability in children with a history of wheezy bronchitis. Archives of Disease in Childhhood, 47, 578.

Matsuba, K., and Thurlbeck, W. M. (1972). A morphometric study of bronchial and bronchiolar walls in children. American Review of Respiratory Disease, 105, 908.

Meisner, P., and Hugh-Jones, P. (1968). Pulmonary function in bronchial asthma. British Medical fournal, 1, 470.

Phelan, P. D., and Williams, H. E. (1969). Sympathomimetic drugs in acute viral bronchiolitis. Their effect on pulmonary resistance. Pediatrics, 44, 493.

Phelan, P. D., Williams, H. E., and Freeman, M. (1967). The disturbance of ventilation in acute viral bronchiolitis. Australian Paediatric Fournal, 4, 96.

Radford, M. (1974). Measurement of airway resistance and thoracic gas volume in infancy. Archives of Disease in Childhood, 49, 611.

Reynolds, E. O. R., and Cook, C. D. (1963). The treatment of bronchiolitis. Fournal of Pediatrics, 63, 1205.

Riding, W. D., Chatterjee, S. S., and Dinda, P. (1969). Clinical trial of a new $\beta$-adrenergic stimulant in asthma. British Fournal of Clinical Practice, 23, 217.

Rooney, J. C., and Williams, H. E. (1971). The relationship between proved viral bronchiolitis and subsequent wheezing. fournal of Pediatrics, 79, 744.

Williams, H., and McNicol, K. N. (1969). Prevalence, natural history, and relationship of wheezy bronchitis and asthma in children. An epidemiological study. British Medical Fournal, 4, 321 .

Wohl, M. E. B., Stigol, L. C., and Mead, J. (1969). Resistance of the total respiratory system in healthy infants and infants with bronchiolitis. Pediatrics, 43, 495.

Wright, F. H., and Beem, M. O. (1965). Diagnosis and treatment. Management of acute viral bronchiolitis in infancy. Pediatrics, 35, 334.

Correspondence to Dr. M. Radford, Department of Child Health, East Wing, Southampton General Hospital, Tremona Road, Shirley, Southampton SO9 4XY. 